\title{
Effect of Cu Addition in Pipeline Steels on Microstructure, Mechanical Properties and Microbiologically Influenced Corrosion
}

\author{
Xian-Bo Shi ${ }^{1,2} \cdot$ Wei Yan' ${ }^{1}$ Mao-Cheng Yan' ${ }^{1}$ Wei Wang' ${ }^{1}$ Zhen-Guo Yang ${ }^{1}$ Yi-Yin Shan' Ke $^{1}$ Yang $^{1}$
}

Received: 24 November 2016/Revised: 9 January 2017/Published online: 17 February 2017

(C) The Chinese Society for Metals and Springer-Verlag Berlin Heidelberg 2017

\begin{abstract}
In the present study, Cu-modified pipeline steels were fabricated to mitigate MIC by the antimicrobial ability of $\mathrm{Cu}$ element. The microstructure, mechanical properties and the antimircobial performance of the $\mathrm{Cu}$-modified steel were systematically investigated. The $\mathrm{Cu}$-modified steels showed good antimicrobial performance with remarkable strength enhancement by nanoscale $\mathrm{Cu}$-rich precipitates and good impact toughness without changing the original base microstructures after the optimal aging treatment of $500{ }^{\circ} \mathrm{C} / 1 \mathrm{~h}$.
\end{abstract}

\section{KEY WORDS: Pipeline steel; Cu addition; Mechanical properties; Microstructure; Antimicrobial performance}

\section{Introduction}

Microbiologically influenced corrosion (MIC) has been recognized as a major problem in many industries such as oil/gas, and water utilities [1-4]. MIC is thought to be responsible for about $20 \%$ of all corrosion damage of metals and building materials [5]. In the natural gas industry, MIC can account for (15-30)\% of corrosion-related pipeline failures [5]. It is therefore important to advance our understanding of MIC and take measures to mitigate MIC. Various physical, chemical or biological strategies have been used for MIC control, including biocides, coatings, cathodic

Available online at http://link.springer.com/journal/40195

Yi-Yin Shan

yyshan@imr.ac.cn

$\triangle$ Ke Yang

kyang@imr.ac.cn

1 Institute of Metal Research, Chinese Academy of Sciences, Shenyang 110016, China

2 University of Chinese Academy of Sciences, Beijing 100049, China protection and biological competition. These strategies have limitations of being expensive, subject to environmental restrictions and sometimes inefficient. It has been widely accepted that MIC is mainly caused by biofilms formed on a metal surface which can change the electrochemical conditions and thus influence the corrosion processes [3]. Once the biofilms were destructed, MIC could be mitigated. As a common alloying element, copper is well known for its antimicrobial effect. For example, in ancient Egypt, Greece and Rome, silver and copper metals were used to clean wounds [6]. As early as in 1885, Milharde successfully developed a Bordeaux mixture containing $\mathrm{Cu}$ ions to kill bacteria. Following this history, many researchers have proved the antibacterial function of $\mathrm{Cu}$ ions and also proposed the relevant antibacterial mechanisms, although the exact mechanisms are still not fully understood $[7,8]$. What will happen if a higher $\mathrm{Cu}$ content was added to pipeline steels? Is it possible to achieve a better combination of strength and antimicrobial activities for pipeline steels? This is a novel and interesting subject. In our recent study, it was reported that addition of $\mathrm{Cu}$ to pipeline steels could be exploited as a potential method for obtaining a high-strength steel together with excellent resistance to hydrogen-induced cracking (HIC) [9]. This is because $\mathrm{Cu}$ is very special 
alloying element in the steel. $\mathrm{Cu}$ could improve mechanical properties and corrosion resistance as well as the cold forming abilities for steels [10-12]. Through adding proper amount of $\mathrm{Cu}$ to steels, it could produce fine $\mathrm{Cu}$-rich precipitates by adjusting the aging treatment. These tiny $\mathrm{Cu}$-rich precipitates in nanoscale could be formed in the steels, which is responsible for the strength increase in the steels. Most importantly, $\mathrm{Cu}$ is one of the rare metallic elements known to exhibit antibacterial property in stainless steels [13, 14]. This gives us an insight that the addition of $\mathrm{Cu}$ to pipeline steels may play an important role in MIC mitigation.

In this study, a series of $\mathrm{Cu}$-modified pipeline steels (1-2 wt\% Cu) were fabricated; they show not only better mechanical properties but also strong antimicrobial performance. The effects of aging and $\mathrm{Cu}$ content on the microstructure and mechanical properties of the steels were investigated systematically. The age hardening response and corresponding mechanical properties as well as the microstructural evolution of the $\mathrm{Cu}$-modified pipeline steels were studied in a wide range of temperature and time. The antimicrobial performance was verified by electrochemical measurement and surface observation in a near-neutral $\mathrm{pH}$ soil environment inoculated with sulfatereducing bacteria $(\mathrm{SRB})$.

\section{Experimental}

\subsection{Materials}

The materials used in this study were newly designed $\mathrm{Cu}$ modified high-strength pipeline steels. They were melted in a $25-\mathrm{kg}$ vacuum induction melting furnace. The analyzed compositions of the steels are listed in Table 1. The $\mathrm{Cu}-$ modified pipeline steels are denoted as 1.0, 1.5 and $2.0 \mathrm{Cu}$ according to their $\mathrm{Cu}$ content. The $\mathrm{X} 80$ steel is also used in this study for comparison. Firstly, the steel ingots were forged into blocks of $70 \mathrm{~mm} \times 70 \mathrm{~mm} \times 80 \mathrm{~mm}$ and then austenitized at $1050{ }^{\circ} \mathrm{C}$ for $2 \mathrm{~h}$. Then, these blocks were hotrolled into plates about $9 \mathrm{~mm}$ thick under a thermomechanical-controlled processing (TMCP) scheme described in Table 2. After final rolling, the fast cooling rate was achieved by water spray, which was based on the measurement of continuous cooling transformation (CCT) diagram obtained on a Gleeble-3800 hot simulator [15].

\subsection{Aging Treatment and Mechanical Properties}

Differential scanning calorimetry (DSC) studies were carried out on the $2.0 \mathrm{Cu}$ and $\mathrm{X} 80$ steels to evaluate the precipitation behavior of $\mathrm{Cu}$. The DSC samples with diameter of $3 \mathrm{~mm}$ and thickness of $2 \mathrm{~mm}$ were ground to 1000\# with sand papers. The test was conducted at a heating rate of $20{ }^{\circ} \mathrm{C} / \mathrm{min}$ on a SETSYS Evolution 18 DSC thermal analyzer using high-purity argon atmosphere. Based on the results of the DSC experiment, the experimental parameters were selected for conducting the aging treatments. The as-rolled samples were subjected to aging treatment at different aging temperatures for various periods of time. For both the $\mathrm{Cu}$-modified and X80 steels, these included 10, $30 \mathrm{~min}, 1,2,5,6,8$ and $10 \mathrm{~h}$ at $450{ }^{\circ} \mathrm{C}$, and 10 , $30 \mathrm{~min}, 1,2$ and $5 \mathrm{~h}$ at 500,550 and $600{ }^{\circ} \mathrm{C}$. After completion of aging treatment, the samples were air-cooled to the room temperature. Hardness measurements were conducted on polished surface of the samples using a Vickers hardness tester with a load of $500 \mathrm{~g}$ for $15 \mathrm{~s}$, and the average value from five different measurements is reported. Based on the hardness measurement, tensile tests were conducted at room temperature at a displacement speed of $5 \mathrm{~mm} / \mathrm{min}$ on a Schenck $100 \mathrm{kN}$ servo-hydraulic testing machine according to GB/T228.1 specification (Metallic materials. Tensile testing. Part 1: Method of test at room temperature). The tensile specimens with a diameter of $3 \mathrm{~mm}$ and a gauge length of $15 \mathrm{~mm}$ were machined from the plates, perpendicular to the rolling direction. To assure the reliability of the tensile results, three specimens were tested to obtain the average value. The errors in the yield strength and tensile strength measurement were about $\pm 2 \%$ and about $\pm 1 \%$ in elongation, respectively. Charpy impact tests were performed at the temperature of $-20{ }^{\circ} \mathrm{C}$ using the sub-size Charpy V-notch $(\mathrm{CVN})$ specimens of $5 \mathrm{~mm} \times 10 \mathrm{~mm} \times 55 \mathrm{~mm}$ according to GB/T229 standard (Metallic materials-Charpy pendulum impact test method). The average of three results was recorded as the impact value for the specimens.

\subsection{Microstructural Characterization}

Microstructures of experimental steels were observed using scanning electron microscopy (SEM) and transmission electron microscopy (TEM). For SEM observation, the

Table 1 Chemical compositions of the experimental steels (wt\%)

\begin{tabular}{lllllllllll}
\hline Steel & $\mathrm{C}$ & $\mathrm{Si}$ & $\mathrm{Mn}$ & $\mathrm{Mo}$ & $\mathrm{Cu}$ & $\mathrm{Ni}$ & $\mathrm{Nb}$ & $\mathrm{S}$ & $\mathrm{P}$ & $\mathrm{Other}$ \\
\hline $1.0 \mathrm{Cu}$ & 0.031 & 0.14 & 1.09 & 0.31 & 1.06 & 0.32 & 0.05 & 0.0011 & 0.005 & $0.32 \mathrm{Cr}$ \\
$1.5 \mathrm{Cu}$ & 0.019 & 0.12 & 1.03 & 0.31 & 1.46 & 0.31 & 0.05 & 0.0011 & 0.005 & $0.31 \mathrm{Cr}$ \\
$2.0 \mathrm{Cu}$ & 0.023 & 0.13 & 1.06 & 0.30 & 2.00 & 0.30 & 0.05 & 0.0010 & 0.005 & $0.30 \mathrm{Cr}$ \\
$\mathrm{X} 80$ & 0.028 & 0.28 & 1.90 & 0.22 & 0.20 & 0.29 & 0.08 & 0.0020 & 0.012 & $0.03 \mathrm{~V}$ \\
\hline
\end{tabular}


Table 2 Procedure of the thermomechanical control process (TMCP) for the Cu-modified pipeline steels

\begin{tabular}{|c|c|c|c|c|c|c|c|c|c|}
\hline \multirow[t]{2}{*}{ Steel } & \multicolumn{7}{|c|}{ Interpass reduction in thickness $(\mathrm{mm})$ and rolling temperature $\left({ }^{\circ} \mathrm{C}\right)$} & \multicolumn{2}{|l|}{ Accelerated cooling } \\
\hline & $78 \rightarrow 62$ & $62 \rightarrow 45$ & $45 \rightarrow 30$ & $30 \rightarrow 24$ & $24 \rightarrow 16$ & $16 \rightarrow 11$ & $11 \rightarrow 9$ & Water cooling rate $\left({ }^{\circ} \mathrm{C} / \mathrm{s}\right)$ & Finishing temperature $\left({ }^{\circ} \mathrm{C}\right)$ \\
\hline $1.0 \mathrm{Cu}$ & 1025 & $*$ & $*$ & 894 & $*$ & $*$ & 835 & 24 & 420 \\
\hline $1.5 \mathrm{Cu}$ & 1030 & $*$ & $*$ & 930 & $*$ & $*$ & 814 & 20 & 416 \\
\hline $2.0 \mathrm{Cu}$ & 1019 & $*$ & $*$ & 923 & $*$ & $*$ & 830 & 27 & 414 \\
\hline
\end{tabular}

* Temperature not measured during the fast rolling process

samples were mechanically ground to $2000 \#$ with sand papers, polished and then etched in a $2 \%$ nital solution. $300-\mu \mathrm{m}$-thick disks were first mechanically thinned to foils about $50 \mu \mathrm{m}$ thick and then electropolished by a twin-jet electropolisher in a solution of $8 \mathrm{vol} \% \%$ perchloric acid and 92 vol.\% ethanol. These foils with very tiny holes were examined by using a TEM (FEI Tecnai $G^{2}$ F20) at an accelerating voltage of $200 \mathrm{kV}$.

\subsection{Microbiologically Influenced Corrosion}

Soils used in this study were taken from Shenyang, China. The soils were dried at $105^{\circ} \mathrm{C}$ for $12 \mathrm{~h}$ and then ground to less than $1 \mathrm{~mm}$ diameter. The soil solution was prepared by extracting the soil with the distilled water/soil ratio of 5:1. The soil solution was autoclaved at $121{ }^{\circ} \mathrm{C}$ for $30 \mathrm{~min}$ and stored at $4{ }^{\circ} \mathrm{C}$ for use. Table 3 shows the analytical results of the soil compositions. The SRB strains used for this study were isolated from the soils. They were anaerobically incubated in the API RP-38 medium with the following compositions: $0.2 \mathrm{~g} / \mathrm{L} \quad \mathrm{MgSO}_{4} \cdot 7 \mathrm{H}_{2} \mathrm{O}, 0.5 \mathrm{~g} / \mathrm{L} \quad \mathrm{KH}_{2} \mathrm{PO}_{4}$, $10.0 \mathrm{~g} / \mathrm{L} \mathrm{NaCl}, 1.0 \mathrm{~g} / \mathrm{L}$ ascorbic acid, $4.0 \mathrm{~g} / \mathrm{L}$ sodium lactate, $1.0 \mathrm{~g} / \mathrm{L}$ yeast extract and $0.02 \mathrm{~g} / \mathrm{L} \mathrm{Fe}\left(\mathrm{NH}_{4}\right)_{2}\left(\mathrm{SO}_{4}\right)_{2}$. The $\mathrm{pH}$ of the culture solution was adjusted to $7.1 \pm 0.1$ by $1 \mathrm{~mol} / \mathrm{L} \mathrm{NaOH}$. The SRB strains were activated in an incubator for $12 \mathrm{~h}$ before the experiment.

For electrochemical measurements, $1.0 \mathrm{Cu}$ and X80 coupons with dimension of $10 \mathrm{~mm} \times 10 \mathrm{~mm} \times 5 \mathrm{~mm}$ were embedded in an epoxy resin, leaving an exposed area of $100 \mathrm{~mm}^{2}$. The coupons were ground to $800 \#$ by sand papers, followed by rinsing with alcohol. A standard threeelectrode electrochemical cell with $1000 \mathrm{ml}$ solution (950 $\mathrm{ml}$ soil solution $+50 \mathrm{ml}$ SRB-inoculated medium) was used for the electrochemical studies. It is composed of test coupons as working electrodes, a platinum electrode as a counter electrode and a saturated calomel electrode (SCE) as a reference electrode. Several coupons were immersed in this cell for surface analysis. Prior to experiment, the cell was purged for $4 \mathrm{~h}$ with pure nitrogen gas to establish an anaerobic environment and then $50 \mathrm{ml} \mathrm{SRB-}$ inoculated medium was injected into the cell by a syringe. Linear polarization resistance $\left(R_{\mathrm{LPR}}\right)$ was monitored on 1.0 $\mathrm{Cu}$ and X80 coupons under biotic condition for 20 days. The measurements were performed using an EG\&G PARSTAT 2273 electrochemical system at temperature of $30{ }^{\circ} \mathrm{C}$. The $R_{\mathrm{LPR}}$ was measured in the range of $\pm 10 \mathrm{mV}$ versus OCP at a scan rate of $0.166 \mathrm{mV} / \mathrm{s}$. After the test, the corrosion products on the surface of the steels were removed according to GB/T 16545-2015 standard and then the pitting morphology was visualized by a field emission scanning electron microscopy (FESEM).

\section{Results}

\subsection{DSC Study}

DSC scans of the as-rolled steels of $2.0 \mathrm{Cu}$ and $\mathrm{X} 80$, measured from $150{ }^{\circ} \mathrm{C}$ to $650{ }^{\circ} \mathrm{C}$, were recorded and are shown in Fig. 1. It is interesting to note that there are three similar exothermic peaks at low temperature $\left(<500{ }^{\circ} \mathrm{C}\right)$, which may be related to tempering of microstructure and recovery of locations therein [16]. The DSC curve of the 2.0Cu steel exhibits an extra exothermic peak at temperature around $550{ }^{\circ} \mathrm{C}$. The corresponding exothermic peak in the case of the X80 steel was not observed. The extra exothermic reaction at $546{ }^{\circ} \mathrm{C}$ for the $2.0 \mathrm{Cu}$ steel indicates the $\mathrm{Cu}$ precipitation process.

Table 3 Compositions of the used soil $(\mu \mathrm{g} / \mathrm{kg}$ soil)

\begin{tabular}{|c|c|c|c|c|c|c|c|c|c|c|c|}
\hline \multirow[t]{2}{*}{$\mathrm{pH}$} & \multicolumn{8}{|c|}{ Chemical composition } & \multirow[t]{2}{*}{ Organic content } & \multirow[t]{2}{*}{ Whole nitrogen content } & \multirow[t]{2}{*}{ Total salt content } \\
\hline & $\mathrm{NO}_{3}^{-}$ & $\mathrm{Cl}^{-}$ & $\mathrm{SO}_{4}^{2-}$ & $\mathrm{HCO}_{3}{ }^{-}$ & $\mathrm{Ca}^{2+}$ & $\mathrm{Mg}^{2+}$ & $\mathrm{K}^{+}$ & $\mathrm{Na}^{+}$ & & & \\
\hline 7.75 & 46 & 31 & 48 & 234 & 57 & 32 & 2 & 14 & $2.26 \times 10^{4}$ & 910 & 464 \\
\hline
\end{tabular}




\subsection{Age Hardening}

Based on the DSC results, the $\mathrm{X} 80$ steel and the $\mathrm{Cu}$ modified steels were aged at $450-600{ }^{\circ} \mathrm{C}$ for various periods of time. The Vickers hardness of the four steels as a function of aging time is shown in Figs. 2 and 3. The hardness of the X80 steel shows slight change upon aging from temperature of $450-600{ }^{\circ} \mathrm{C}$ (Fig. 2a). After adding $(1-2) \% \mathrm{Cu}$ to the steel, there is an obvious change in hardness, as can be observed in Fig. 2b-d. The hardness reaches the highest values of 235,257 and $280 \mathrm{HV}$ for the $1.0,1.5$ and $2.0 \mathrm{Cu}$ steels, respectively, if the aging time is fixed at $1 \mathrm{~h}$. Moreover, at $500{ }^{\circ} \mathrm{C}$, the peak hardness was reached for the steels after aging for $1 \mathrm{~h}$. With further increase in the aging time, the hardness decreases, indicating that an over-aging effect occurs. This reduction in hardness is attributed to the combined effect of microstructural softening due to recovery and coarsening of $\mathrm{Cu}$-rich precipitates at higher aging temperatures and for a longer aging time. However, the peak-aging has not been reached aging at $450{ }^{\circ} \mathrm{C}$ within $5 \mathrm{~h}$. Extending the aging time up to $10 \mathrm{~h}$, the highest values of 251,272 and $288 \mathrm{HV}$ for the 1.0, 1.5 and 2.0 Cu steels, respectively, were reached at around $6 \mathrm{~h}$ (Fig. 3a). In order to analyze the effect of aging temperature on peak-aging time, the curves of hardness versus aging time at different aging temperatures are presented in Fig. 3. As can be observed, the peak-aging time was around $6,1,0.5 \mathrm{~h}$ and $10 \mathrm{~min}$ for the $\mathrm{Cu}$-modified steels aged at $450,500,550$ and $600{ }^{\circ} \mathrm{C}$, respectively. Obviously, the peak-aging time decreases with increase in the aging temperature.

The increase in hardness on peak-aging, $\Delta H_{\text {peak }}$, is summarized in Table 4. For the same $\mathrm{Cu}$ content, $\Delta H_{\text {peak }}$ decreases as aging temperature increases because of overaging (in terms of temperature) effect and aging softening

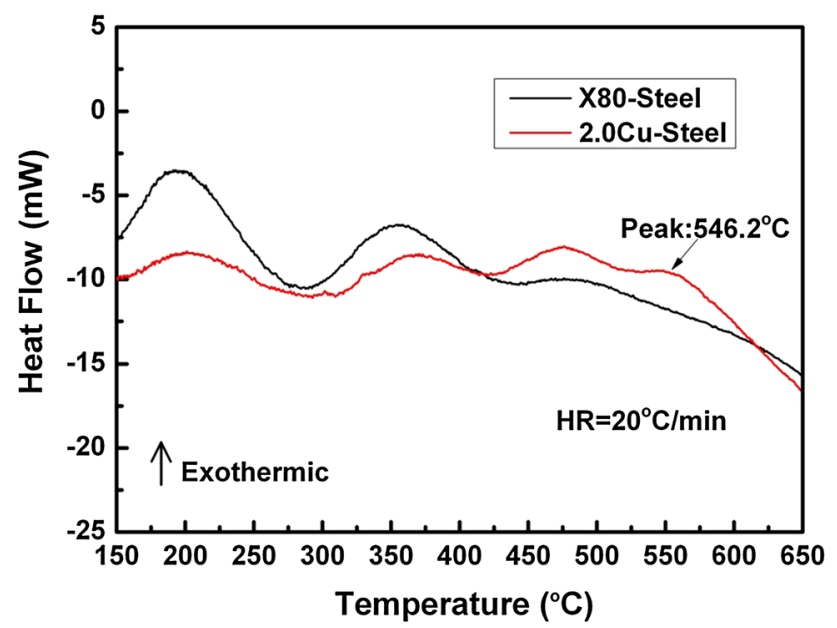

Fig. 1 DSC thermograms showing the additional exothermic peak at $546{ }^{\circ} \mathrm{C}$ for the $2.0 \mathrm{Cu}$ steel compared with the X80 steel due to recovery at higher temperatures. Moreover, $\Delta H_{\text {peak }}$ reached the highest value for the $1.5 \mathrm{Cu}$ steel at all the aging temperatures, indicating that the optimal $\mathrm{Cu}$ content is $1.5 \%$ with the highest hardness increase.

\subsection{Tensile Properties}

Room temperature tensile and impact tests were performed to investigate the influence of aging on mechanical properties of the $\mathrm{Cu}$-modified pipeline steels. The tensile and impact specimens of three $\mathrm{Cu}$-modified steels were aged at $450{ }^{\circ} \mathrm{C}$ for $6 \mathrm{~h}$ and $500{ }^{\circ} \mathrm{C}$ for $1 \mathrm{~h}$, corresponding to the peak precipitation strengthening as identified above. For comparison, the tensile and impact tests were also conducted on the specimens aged at $550{ }^{\circ} \mathrm{C}$ for $1 \mathrm{~h}$. Firstly, the mechanical properties, namely yield strength, tensile strength, elongation and impact toughness of three $\mathrm{Cu}$ modified steels and the X80 steel in as-rolled condition are presented in Table 5. It can be found that with increase in the $\mathrm{Cu}$ content, the strength of the steels was increased and impact toughness was decreased. It can also be observed that the hot-rolled $\mathrm{Cu}$-modified steels showed lower yield strength compared to the X80 steel. There may be two reasons for this phenomenon. (a) Hot-rolled $\mathrm{Cu}$-modified steels have lower C (1.5 and 2.0Cu steels) and Mn contents compared to the $\mathrm{X} 80$ steel, which are two major strengthening elements in these steels. (b) Although the 1.0 $\mathrm{Cu}$ steel has higher $\mathrm{C}$ content than the X80 steel, solid solution strengthening effect of $\mathrm{Cu}$ is very small because of its similar radius to $\mathrm{Fe}$ atoms. Nonetheless, the as-rolled $2.0 \mathrm{Cu}$ steel displays a higher tensile strength than the X80 steel. The $\mathrm{Cu}$-modified steels in as-rolled condition have lower yield/tensile ratios. It is believed that the deformability of the steel is improved by lowering yield/tensile ratio [17]. Therefore, the $\mathrm{Cu}$-modified steels possess higher deformability than the traditional X80 steel. This is confirmed by the $\mathrm{Cu}$-modified steels exhibiting higher elongations than the X80 steel. The tensile results for the $\mathrm{Cu}$ modified steels subjected to aging after hot rolling are presented in Fig. 4. Compared with the as-rolled steels, both yield strength and tensile strength of the aged steels are remarkably improved, which evidently proved that the precipitation strengthening in steels took place through aging. The yield strength and tensile strength are well in agreement with the results of age hardening in Sect. 3.2. The optimum strength values were reached in the condition of aging at $450{ }^{\circ} \mathrm{C}$ for $6 \mathrm{~h}$ and $500{ }^{\circ} \mathrm{C}$ for $1 \mathrm{~h}$. Figure 5 presents the increment of strength between the different $\mathrm{Cu}$-modified steels as-rolled and aged at $500{ }^{\circ} \mathrm{C}$ for $1 \mathrm{~h}$. Substantial increases in yield strength and tensile strength are observed in the $\mathrm{Cu}$-modified steels. There are about 200, 215 and $225 \mathrm{MPa}$ increments of yield strength for the $1.0,1.5$ and $2.0 \mathrm{Cu}$ steels, respectively, and there are about 

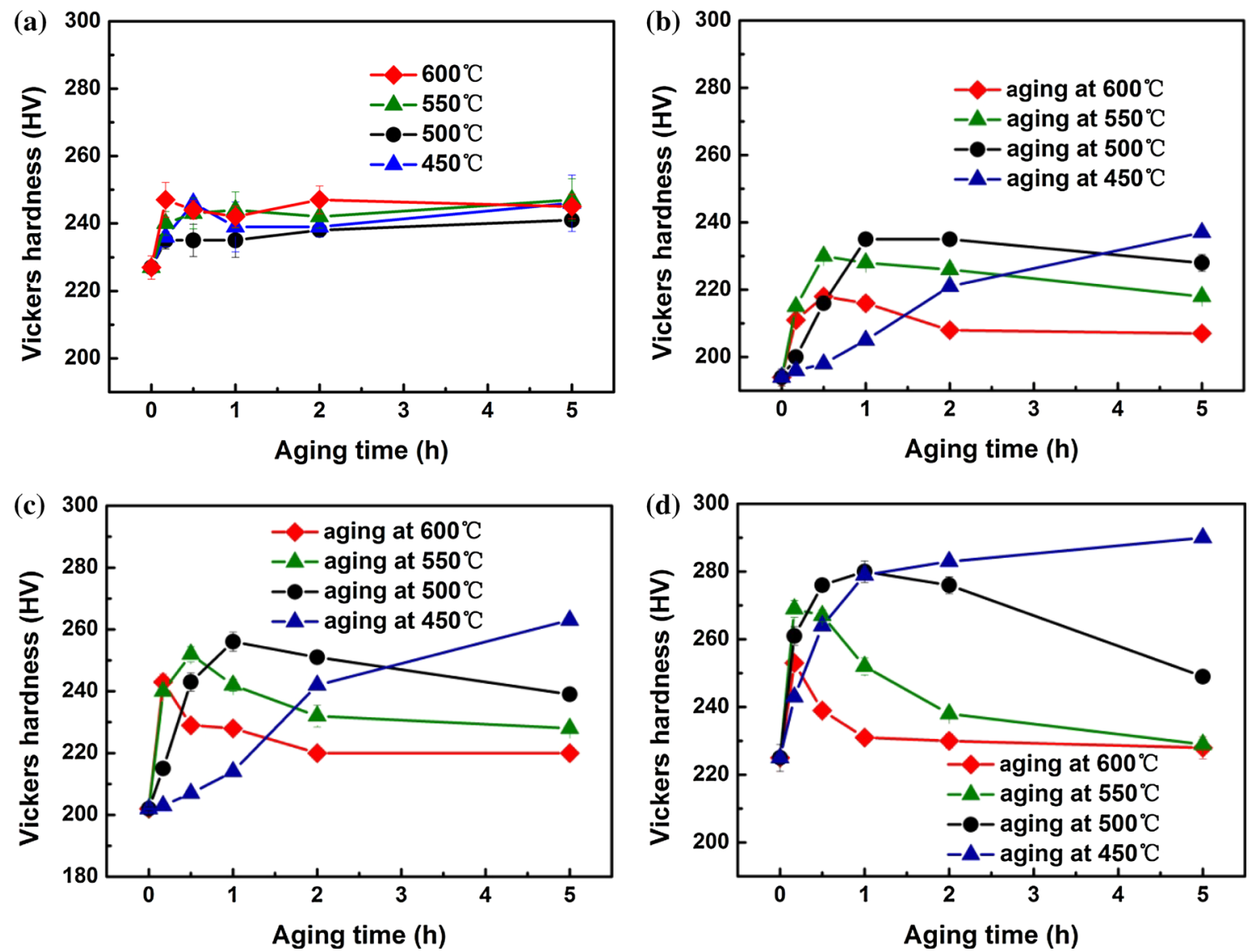

Fig. 2 Hardness of various $\mathrm{Cu}$-modified steels as a function of aging time a X80 for comparison, $\mathbf{b} 1.0 \mathrm{Cu}, \mathbf{c} 1.5 \mathrm{Cu}, \mathbf{d} 2.0 \mathrm{Cu}$

70, 150 and $150 \mathrm{MPa}$ increments of tensile strength for the 1.0, 1.5 and $2.0 \mathrm{Cu}$ steels, respectively. These results once more suggest that the optimal $\mathrm{Cu}$ content in the present investigation is $1.5 \%$.

\subsection{Impact Toughness}

Figure 6 shows the effect of $\mathrm{Cu}$ content on the impact toughness of as-rolled steels and those aged at various temperatures and times. The impact result of the X80 steel is also given in Fig. 6 for comparison. As can be seen, the impact toughness is decreased with increase in the $\mathrm{Cu}$ content, and the 1.0 Cu steel in as-rolled condition displays comparable impact toughness with the X80 steel. For asrolled steels, $\mathrm{Cu}$ contributed to the strength via solution strengthening. For aging steels, $\mathrm{Cu}$ mainly contributed to the strength by precipitation strengthening. Both the strengthening techniques could increase the strength with increase in $\mathrm{Cu}$ but decrease in toughness. Therefore, the more $\mathrm{Cu}$ the steel contains, the lower the impact toughness of the steel was obtained in the present study. Moreover, the impact toughness was deteriorated after aging treatment. For the same $\mathrm{Cu}$ content, there is some increase in impact toughness with the increase in the aging temperature for the $\mathrm{Cu}$-modified steels. Aging at $550{ }^{\circ} \mathrm{C}$ for $1 \mathrm{~h}$ has resulted in slightly higher energy absorption than aging at $500{ }^{\circ} \mathrm{C}$. However, the tensile stress, especially for the $2.0 \mathrm{Cu}$ steel, was reduced significantly after aging at $550{ }^{\circ} \mathrm{C}$ (Fig. 4). Thus, the above results indicate that the aging treatment at $500{ }^{\circ} \mathrm{C}$ for $1 \mathrm{~h}$ provides an appropriate condition for obtaining a substantial strength response with good impact toughness.

\subsection{Microstructural Characterization}

Figure 7 shows the representative SEM micrographs of the $\mathrm{Cu}$-modified steels and the X80 steel, in the as-rolled and aged conditions. For the as-rolled samples, it can be seen that the $1.0 \mathrm{Cu}$ steel presents a polygonal ferrite (PF)dominated microstructure (Fig. 7a). The microstructure is not homogeneous, and the grain size varies in the range of $2-10 \mu \mathrm{m}$. It is clear to distinguish the grains according to their sizes. When the $\mathrm{Cu}$ content is increased to $1.5 \%$, the steel consists of a quasi-polygonal ferrite (QF)-dominated microstructure mixed with polygonal ferrite (PF) with grain size changing from 4 to $10 \mu \mathrm{m}$ (Fig. 7b). It can be seen that the microstructures of the as-rolled $2.0 \mathrm{Cu}$ steel (Fig. 7c) and the X80 steel (Fig. 7d) exhibit a typical 

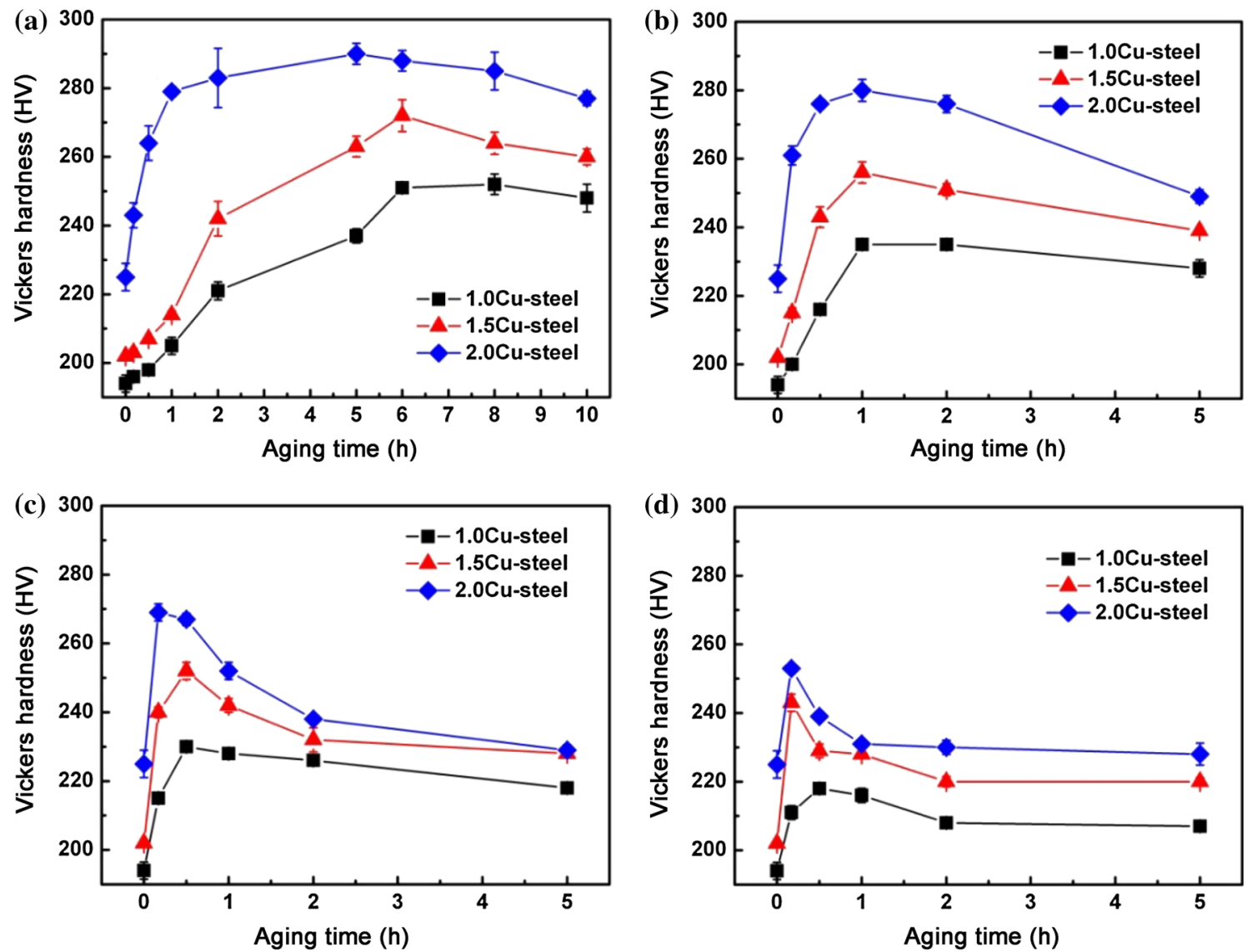

Fig. 3 Hardness as a function of aging time at different aging temperatures, a $450{ }^{\circ} \mathrm{C} ; \mathbf{b} 500{ }^{\circ} \mathrm{C}$; c $550{ }^{\circ} \mathrm{C}$; d $600{ }^{\circ} \mathrm{C}$

Table 4 Increase in hardness (HV) due to peak-aging at different aging temperatures

\begin{tabular}{lllll}
\hline Steel & $450{ }^{\circ} \mathrm{C}$ & $500{ }^{\circ} \mathrm{C}$ & $550{ }^{\circ} \mathrm{C}$ & $600{ }^{\circ} \mathrm{C}$ \\
\hline $1.0 \mathrm{Cu}$ & 58.0 & 41.0 & 36.3 & 24.0 \\
$1.5 \mathrm{Cu}$ & 70.0 & 54.6 & 50.3 & 41.3 \\
$2.0 \mathrm{Cu}$ & 65.3 & 53.5 & 44.3 & 28.0 \\
\hline
\end{tabular}

acicular ferrite (AF) microstructure. A remarkable characteristic of this type of microstructure presents a unique and irregular configuration, which has various grain sizes distributed in a chaotic manner with random orientations [18]. Obviously, the microstructure of the $2.0 \mathrm{Cu}$ steel is more uniform than those of the 1.0 and $1.5 \mathrm{Cu}$ steels. In contrast to the as-rolled samples, the microstructures of the aged samples subjected to $500{ }^{\circ} \mathrm{C} / 1 \mathrm{~h}$ still keep the same ferrite characteristic but become homogeneous (Fig. 7e-h). The non-uniform grain size and acicular ferrite characteristics as well as $\mathrm{Cu}$-rich precipitates have been reported in one of our previous work [9]. The precipitates in both $1.0 \mathrm{Cu}$ steel and $1.5 \mathrm{Cu}$ steels show a size with diameter of about $10 \mathrm{~nm}$, while they are about $20 \mathrm{~nm}$ in the $2.0 \mathrm{Cu}$ steel. The $\mathrm{Cu}$-rich precipitates became denser with increase in $\mathrm{Cu}$ content in the steel.

The $2.0 \mathrm{Cu}$ steel was selected to investigate the effect of aging on the $\mathrm{Cu}$-rich precipitate evolution. Figure 8 shows the bright-field TEM micrographs of steels after aging at different temperatures and time. High-density particles

Table 5 Mechanical properties of the as-rolled steels

\begin{tabular}{|c|c|c|c|c|}
\hline Steel & Yield strength (MPa) & Tensile strength (MPa) & Elongation (\%) & Impact toughness $\left(-20^{\circ} \mathrm{C}\right)(\mathrm{J})$ \\
\hline $1.0 \mathrm{Cu}$ & 443 & 651 & 30.0 & 141 \\
\hline $1.5 \mathrm{Cu}$ & 513 & 645 & 28.0 & 82 \\
\hline $2.0 \mathrm{Cu}$ & 608 & 759 & 25.0 & 66 \\
\hline X80 & 608 & 677 & 23.5 & 140 \\
\hline
\end{tabular}




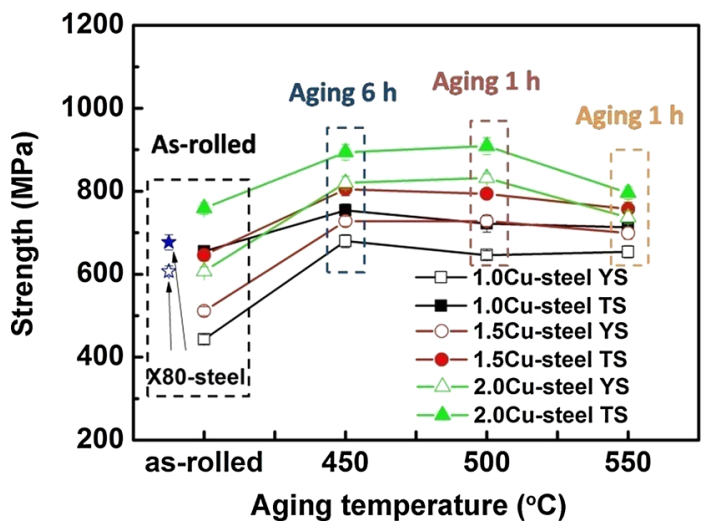

Fig. 4 Variation of yield strength (YS) and tensile strength (TS) with $\mathrm{Cu}$ content for the as-rolled and aged $\left(450{ }^{\circ} \mathrm{C} / 6 \mathrm{~h}, 500{ }^{\circ} \mathrm{C} / 1 \mathrm{~h}\right.$, $550{ }^{\circ} \mathrm{C} / 1 \mathrm{~h}$ ) steels. Open and filled symbols represent YS and TS, respectively

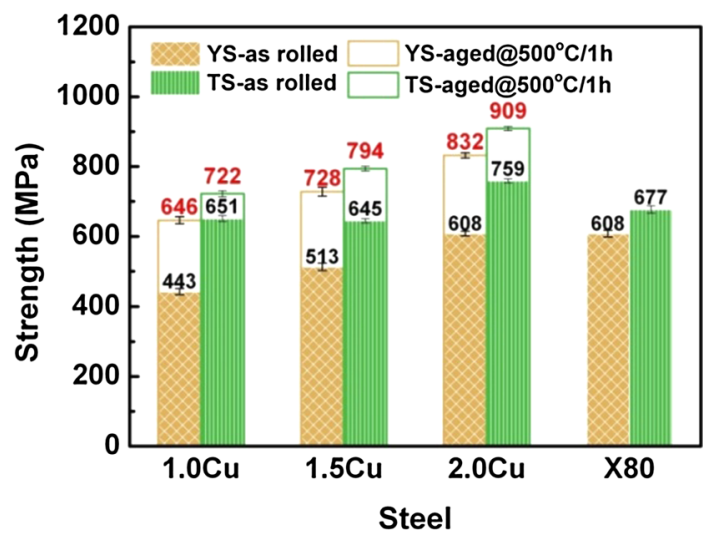

Fig. 5 Increment of strength between as-rolled and aged steels with different $\mathrm{Cu}$ content

could be observed in the steel aged at $450{ }^{\circ} \mathrm{C}$ for $6 \mathrm{~h}$ (Fig. 8a). This is consistent with the result of hardness measurements in Fig. 3a. It can be found that there are very fine precipitates interacting with the dislocations in the steel aged at $500{ }^{\circ} \mathrm{C}$ for $10 \mathrm{~min}$ (Fig. 8b). The $\mathrm{Cu}$-rich precipitates have not enough time to precipitate completely during this short time. However, the hardness increase is higher compare with other steels (Fig. 3b), indicating that the formation of $\mathrm{Cu}$-rich precipitates should be very fast in the $2.0 \mathrm{Cu}$ steel. When the steel was aged at $500{ }^{\circ} \mathrm{C}$ for $5 \mathrm{~h}$, the precipitate size was bigger and the density of precipitates was larger (Fig. 8c). The same trend was also observed in the steel aged at $550{ }^{\circ} \mathrm{C}$. The precipitate size and the number density were increased with increase in the aging time (Fig. 8d-f). Figure 9 shows the average size determined by image analysis, which demonstrates this trend for the $2.0 \mathrm{Cu}$ steel under different aging conditions. Upon aging at $500{ }^{\circ} \mathrm{C}$, the average size of the $\mathrm{Cu}$-rich particles increases continuously from $11 \pm 2 \mathrm{~nm}$ aged for $10 \mathrm{~min}$ to $16 \pm 4 \mathrm{~nm}$ for $1 \mathrm{~h}$ and further to $26 \pm 6 \mathrm{~nm}$ for

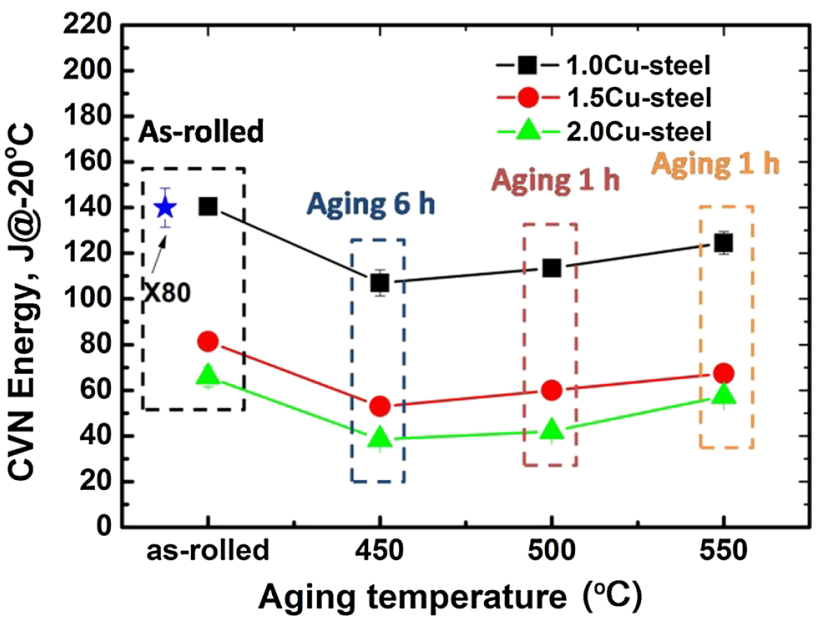

Fig. 6 Variation of impact toughness at $-20{ }^{\circ} \mathrm{C}$ with $\mathrm{Cu}$ content for the as-rolled and aged $\left(450{ }^{\circ} \mathrm{C} / 6 \mathrm{~h}, 500{ }^{\circ} \mathrm{C} / 1 \mathrm{~h}, 550{ }^{\circ} \mathrm{C} / 1 \mathrm{~h}\right)$ steels

$5 \mathrm{~h}$. Aging at $550{ }^{\circ} \mathrm{C}$, the average size of the $\mathrm{Cu}$-rich particles increases from $20 \pm 4 \mathrm{~nm}$ aged for $10 \mathrm{~min}$ to $24 \pm 6 \mathrm{~nm}$ for $1 \mathrm{~h}$ and further to $34 \pm 7 \mathrm{~nm}$ for $5 \mathrm{~h}$.

\subsection{Antimicrobial Performance}

The $1.0 \mathrm{Cu}$ steel (aged at $500{ }^{\circ} \mathrm{C}$ for $1 \mathrm{~h}$ ) and $\mathrm{X} 80$ steel were used to verify the effect of $\mathrm{Cu}$ on the antimicrobial performance in the soil environment. The linear polarization resistances $\left(R_{\mathrm{LPR}}\right)$ of the two steels are compared in Fig. 10 as a function of time. As can be seen, the two steels show the similar $R_{\mathrm{LPR}}$ values during the initial 4 days. From the day 2 to $6, R_{\mathrm{LPR}}$ of the X80 steel declines sharply and reaches a minimum of $5.2 \mathrm{k} \Omega \mathrm{cm}^{2}$ on day 6 , and then gradually increases to a steady state of $8.2 \mathrm{k} \Omega \mathrm{cm}^{2}$. In contrast, $R_{\mathrm{LPR}}$ of the $1.0 \mathrm{Cu}$ steel increases from $11.4 \mathrm{k} \Omega \mathrm{cm}^{2}$ on day 5 to $22.6 \mathrm{k} \Omega \mathrm{cm}^{2}$ on day 9 , and then the $1.0 \mathrm{Cu}$ steel is typically $11-17 \mathrm{k} \Omega \mathrm{cm}^{2}$ noble than that of X80 steel. It is known that the corrosion rate is inversely related to the $R_{\mathrm{LPR}}$ value. This clearly indicates that SRBinfluenced corrosion is inhibited by the nanoscale $\mathrm{Cu}$-rich particles in the matrix of the $1.0 \mathrm{Cu}$ steel. The growth curve of SRB as a function of time is also shown in Fig. 10. The planktonic SRB experiences a rapid growth during the first 3 days, reaches the maximum from day 4 to 6 and then decreases sequentially. The trends of $R_{\mathrm{LPR}}$ match well with the growth phase of planktonic SRB.

Figure 11 shows the corroded appearance of two steels after 20 days exposure to SRB-inoculated soil solution. For the $1.0 \mathrm{Cu}$ steel, the scratches from pretreatment are clear on the surface (Fig. 11a). Some tiny pits are observed on the surface. However, there are more pits on the X80 coupon than that of on the 1.0Cu coupon, and these pits are of high-density and larger diameter. It is apparent that SRB induced serious pitting corrosion on the X80 steel compare 

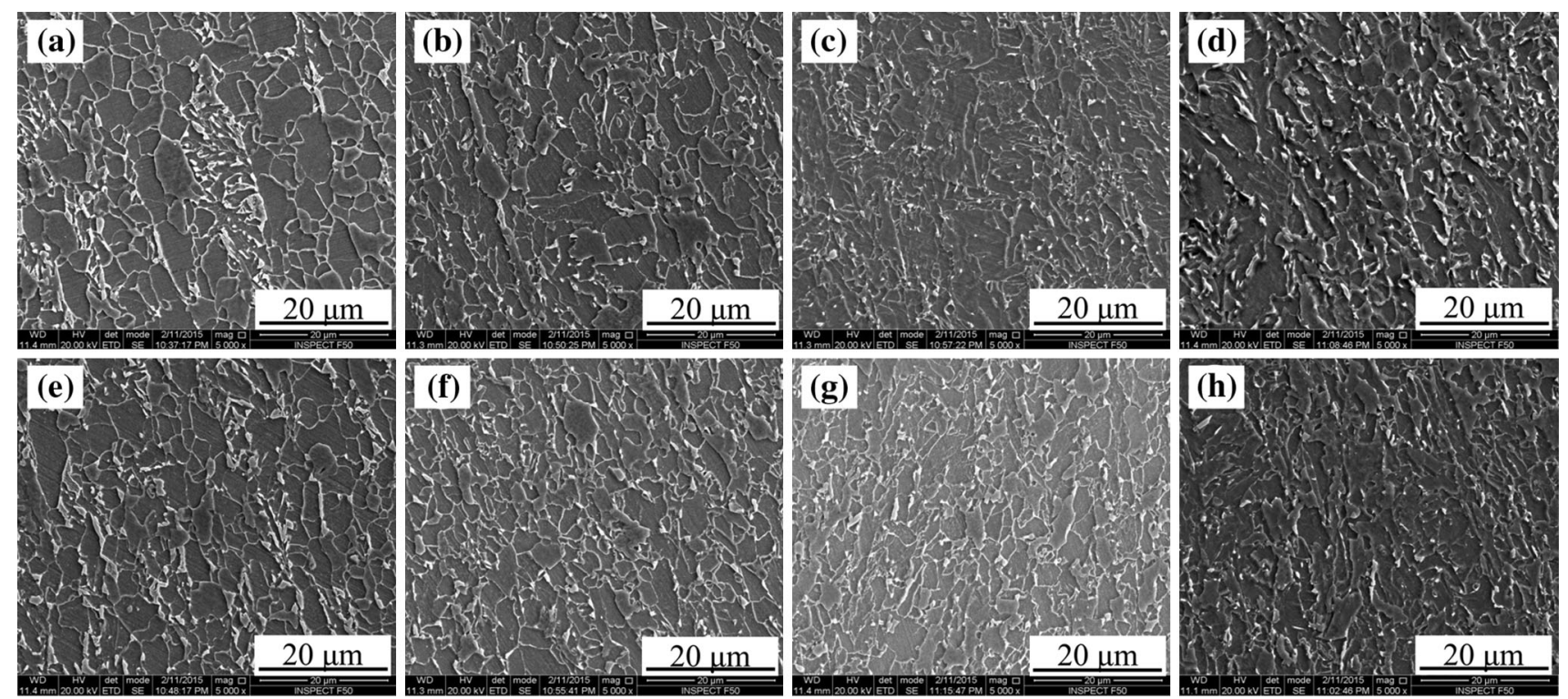

Fig. 7 SEM microstructures of $\mathrm{Cu}$-modified pipeline steels and the $\mathrm{X} 80$ steel, a $1.0 \mathrm{Cu}$ steel as-rolled; $\mathbf{b} 1.5 \mathrm{Cu}$ steel as-rolled; $\mathbf{c} 2.0 \mathrm{Cu}$ steel asrolled; d X80 steel as-rolled; e1.0Cu steel $500{ }^{\circ} \mathrm{C} / 1 \mathrm{~h} ; \mathbf{f} 1.5 \mathrm{Cu}$ steel $500{ }^{\circ} \mathrm{C} / 1 \mathrm{~h} ; \mathbf{g} 2.0 \mathrm{Cu}$ steel $500{ }^{\circ} \mathrm{C} / 1 \mathrm{~h} ; \mathbf{h}$ X80 steel $500{ }^{\circ} \mathrm{C} / 1 \mathrm{~h}$
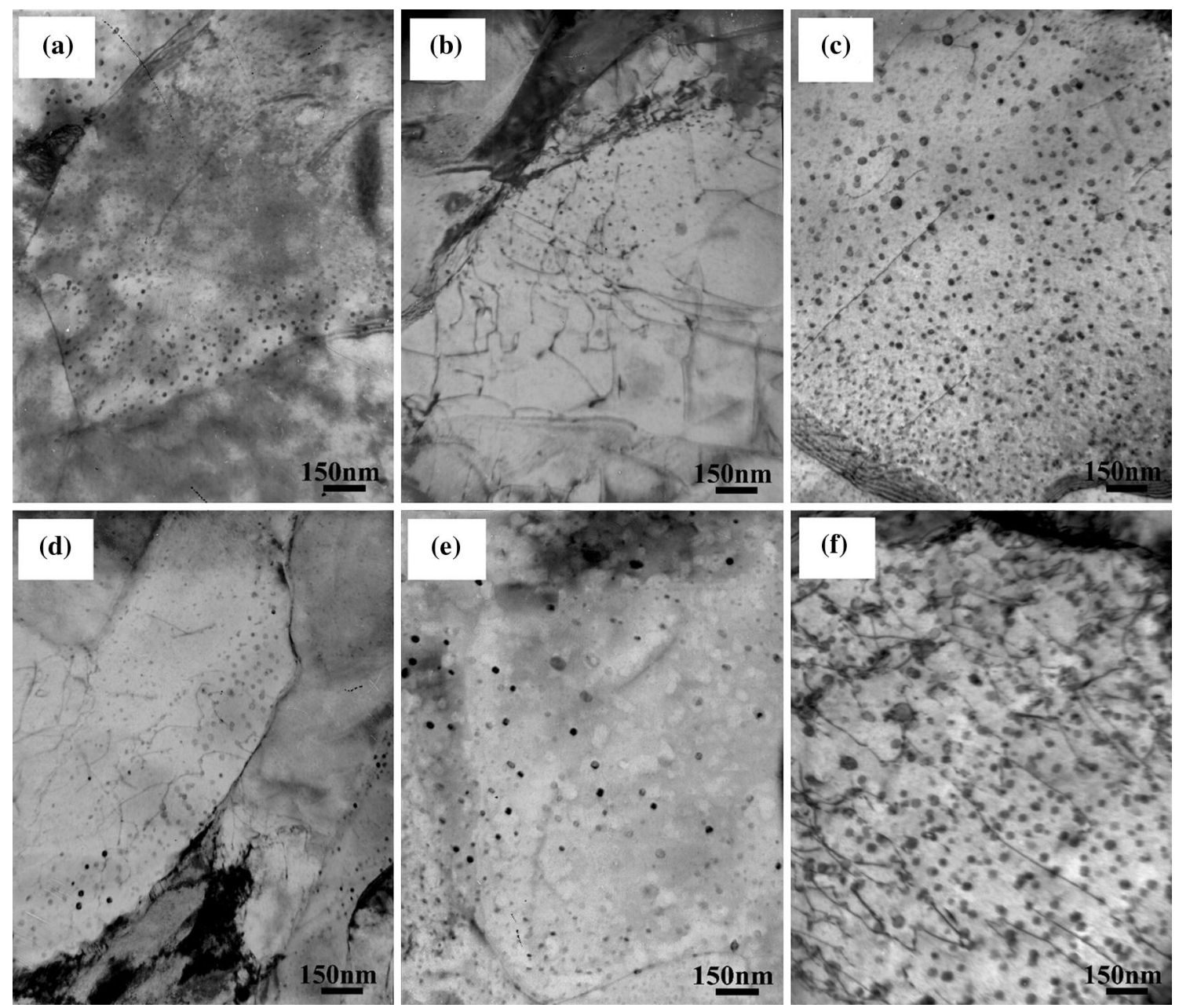

Fig. 8 Bright-field TEM micrographs showing nanoscale copper-rich precipitates in the $2.0 \mathrm{Cu}$ steel under different aging conditions, $\mathbf{a} 450{ }^{\circ} \mathrm{C} /$ $6 \mathrm{~h} ; \mathbf{b} 500{ }^{\circ} \mathrm{C} / 10 \mathrm{~min} ; \mathbf{c} 500{ }^{\circ} \mathrm{C} / 5 \mathrm{~h} ; \mathbf{d} 550{ }^{\circ} \mathrm{C} / 10 \mathrm{~min} ;$ e $550{ }^{\circ} \mathrm{C} / 1 \mathrm{~h} ;$ f $550{ }^{\circ} \mathrm{C} / 5 \mathrm{~h}$ 


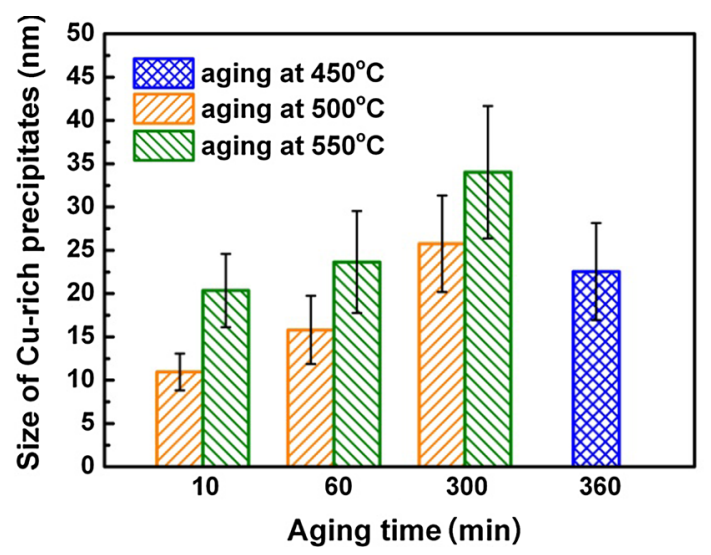

Fig. 9 Average size of $\mathrm{Cu}$-rich precipitates in the $2.0 \mathrm{Cu}$ steel under different aging conditions

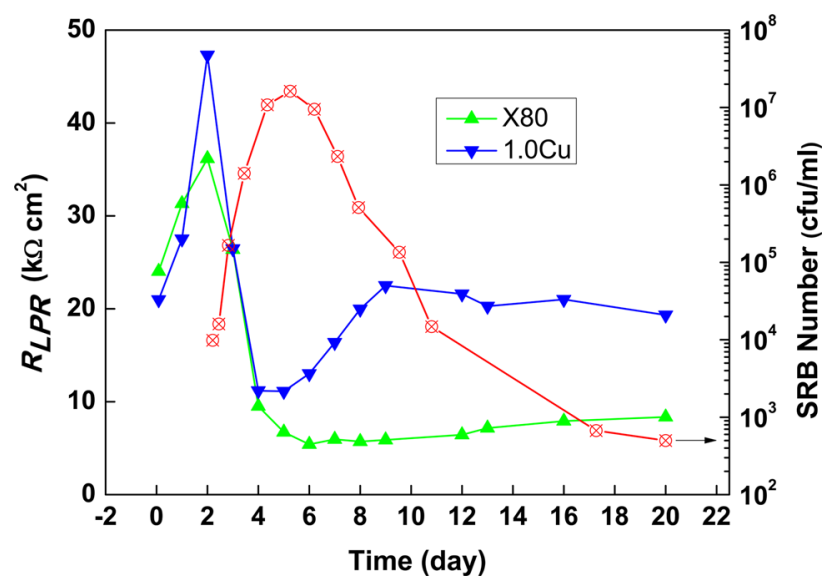

Fig. 10 Variations of $R_{\mathrm{LPR}}$ with exposure time for $\mathrm{X} 80$ and $1.0 \mathrm{Cu}$ steels in the soil solution with SRB

with $1.0 \mathrm{Cu}$ steel. The values of $R_{\mathrm{LPR}}$ of two steels match well with the corroded appearance.

\section{Discussion}

\subsection{Effect of Aging on Hardness for Cu-modified Steels}

From the thermodynamic point of view, the age hardening behavior of $\mathrm{Cu}$ in steel depends on the $\mathrm{Cu}$ content, aging temperature and time. Only an overall effect can be observed on the aging curves (Figs. 2, 3). It is noted that typical age hardening and over-aging softening behavior was observed in the $\mathrm{Cu}$-modified steels, and the extent of age hardening was increased with deceasing aging temperature (Fig. 2b-d). This effect can be attributed to the finer precipitate dispersions generated at lower aging temperature (Fig. 8a). In addition, the increment of hardness is significantly increased with increase in the aging temperature and $\mathrm{Cu}$ content in a short aging time (Fig. 3).This means that there is no significant free energy barrier for the nucleation process at these temperatures [19]. Seko et al. [20] reported that the critical energy required for nucleation was very low in a binary $\mathrm{Fe}-\mathrm{Cu}$ alloy. Viswanathan et al. [21] reported that there was no incubation period for the onset of $\mathrm{Cu}$-rich precipitation in the 17-4 precipitation hardening stainless steel. Same result was also reported by Mirzadeh and Najafizadeh [19]. These simulation predictions and experimental results are all in agreement with the present results, where the $\mathrm{Cu}$-modified steels had a very short incubation period for the $\mathrm{Cu}$-rich phase precipitation (Fig. 3). Therefore, the precipitation and coarsening of $\mathrm{Cu}$-rich particles are mainly determined by the diffusion of $\mathrm{Cu}$ atoms. The size of $\mathrm{Cu}$-rich precipitates in the steel matrix can be described by the following equation [22]:

$S=\alpha(D t)^{1 / 2}$,

where $S$ is the average size of $\mathrm{Cu}$-rich precipitates, $\alpha$ is determined by the concentration difference of $\mathrm{Cu}$ between the $\mathrm{Cu}$-rich precipitate and the steel matrix, $t$ is the aging time and $D$ is the diffusion coefficient of $\mathrm{Cu} . D$ is determined by the following Arrhenius equation:

$D=D_{0} \exp \left(-\frac{Q}{R T}\right)$

where $D_{0}$ is a constant determined by the diffusion mechanism and materials, $R$ is the ideal gas constant, $T$ represents the temperature in Kelvin and $Q$ is the activation energy for the diffusion of $\mathrm{Cu}$ atoms.

A higher $\mathrm{Cu}$ content increases the average size of $\mathrm{Cu}$ rich precipitates and the number density of $\mathrm{Cu}$-rich precipitates [9]. With increasing aging temperature, the diffusion coefficient $D$ in the above equations would increase rapidly, and with prolonging aging time $t$, the size of $\mathrm{Cu}$ rich precipitates would also increase. Both parameters could increase the size of $\mathrm{Cu}$-rich precipitates in the steel matrix. Consequently, the over-aging softening and coarsening behavior of $\mathrm{Cu}$-rich precipitates in the $\mathrm{Cu}$-modified steels are apparent after aging at $550{ }^{\circ} \mathrm{C}$ for $5 \mathrm{~h}$ (Fig. 8f).

On the other hand, the age hardening results indicate that the aging response was significantly accelerated by aging temperature for the $\mathrm{Cu}$-modified steels. The $\mathrm{Cu}$ modified steels reached peak hardness after about $6 \mathrm{~h}$ aging at $450{ }^{\circ} \mathrm{C}$ and $1 \mathrm{~h}$ at $500{ }^{\circ} \mathrm{C}$. However, it was about $0.5 \mathrm{~h}$ at $550{ }^{\circ} \mathrm{C}$ and $10 \mathrm{~min}$ at $600{ }^{\circ} \mathrm{C}$ (Fig. 3). The elevated temperature accelerates aging of the $\mathrm{Cu}$-modified steels because of increasing diffusion rate of $\mathrm{Cu}$, which in turn enhances both nucleation and growth of $\mathrm{Cu}$-rich precipitates. In the present study, the $1.5 \mathrm{Cu}$ steel was selected to analyze the effect of aging temperature on the peak-aging 

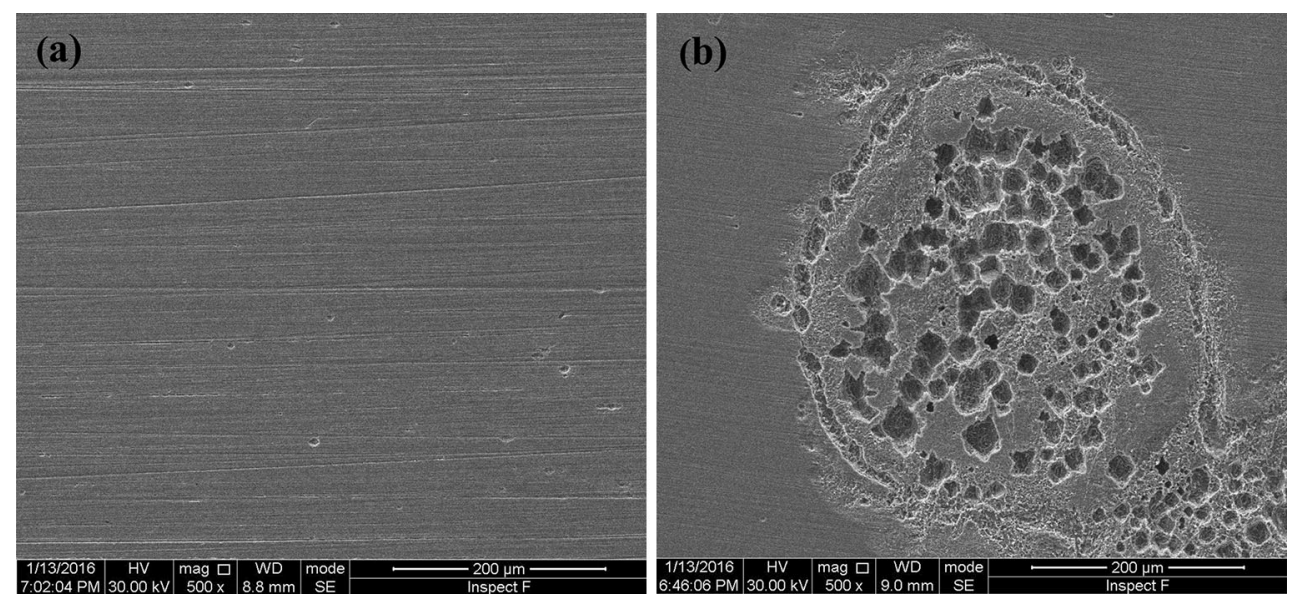

Fig. 11 Morphologies of $1.0 \mathrm{Cu}$ steel $\mathbf{a}$ and X80 steel $\mathbf{b}$ exposed to soil solution with SRB after removing corrosion products

time. According to the method applied by Rana et al. [23] for age hardening of $\mathrm{Cu}$-alloyed IF steel, at any fixed temperature $T$, the extent of aging is governed by the temperature-corrected time $P$, defined by

$P=\frac{t}{T} \exp \left(-\frac{Q}{R T}\right)$

where $t$ is the aging time, $Q$ is the effective activation energy and $R$ is the ideal gas constant. Equation (3) provides a useful way for comparing aging data at different aging time and temperatures. From Eq. (3), the peak-aging time, $t_{\text {peak }}$, can be defined as

$t_{\text {peak }}=\left(T \cdot P_{\text {peak }}\right) \cdot \exp \left(\frac{Q}{R T}\right)$,

where $P_{\text {peak }}$ is the temperature-corrected peak-aging time, $\mathrm{s} / \mathrm{K}$. Taking experimental $t_{\text {peak }}$ values of $6 \mathrm{~h}, 1 \mathrm{~h}, 0.5 \mathrm{~h}$ and $10 \mathrm{~min}$, and using the values of the corresponding $T$ in the experiment, ideally a linear plot of $\ln \left(t_{\text {peak }} / T\right)$ against $1 / R T$ can be made from Eq. (4). The slope of the curve is $Q$ and

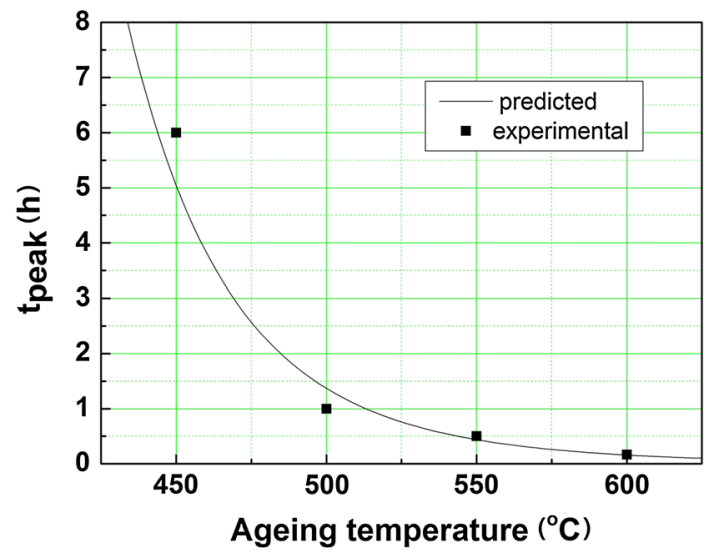

Fig. 12 Experimental peak-aging time of $1.5 \mathrm{Cu}$ steel and its predicted peak-aging time the intercept is $\ln \left(P_{\text {peak }}\right)$. Thus, for the $1.5 \mathrm{Cu}$ steel, $Q=127 \pm 13 \mathrm{~kJ} / \mathrm{mol}$ and $P_{\text {peak }}=1.59 \times 10^{-8} \mathrm{~s} / \mathrm{K}$ were calculated by regression analysis with a correlation coefficient of 0.99. This approach describes the temperature dependence of peak-aging time and is illustrated in Fig. 12. Similar result has been reported by Rana et al. [23]. The time for peak-aging, $t_{\text {peak }}$, decreases as the aging temperature increases. However, the calculated activation energy from Eq. (4) in this work is higher than that of their result $(74 \mathrm{~kJ} / \mathrm{mol})$. Nonetheless, this trend agrees well with the calculated activation energy of $109 \pm 2 \mathrm{~kJ} / \mathrm{mol}$ for another Cu-alloyed HSLA steel [24].

\subsection{Effect of $\mathrm{Cu}$ Content on Microstructure and Mechanical Properties}

$\mathrm{Cu}$ addition would affect the microstructure of the steels (Fig. 7). The 1.0Cu steel showed a polygonal ferritedominated microstructure (Fig. 7a), but the $1.5 \mathrm{Cu}$ steel still gave a mixed microstructure of quasi-polygonal ferrite and polygonal ferrite (Fig. 7b). Further increasing the $\mathrm{Cu}$ content, an acicular ferrite (AF) microstructure was formed in the 2.0Cu steel (Fig. 7c). It has been known that $\mathrm{Cu}$ is an austenite stabilizer in steels and possibly reduces the austenite-to-ferrite transformation temperature. Thus, the high-temperature transformation phase such as pearlite and polygonal ferrite would be suppressed [25]. To verify this possibility, the 1.5 and $2.0 \mathrm{Cu}$ steels with similar carbon concentration were selected to measure the continuous cooling transformation (CCT) diagrams. The transformation temperatures of two steels are shown as a function of cooling rate in Fig. 13. It is evident that the austenite-toferrite transformation temperature is lowered by adding more $\mathrm{Cu}$, and the lowering austenite-to-ferrite transformation temperature could lead to an increase in the driving force for the acicular ferrite transformation (Fig. 13b). 
Accordingly, the microstructure would be transformed from polygonal ferrite to acicular ferrite under a given cooling rate. Furthermore, the solute $\mathrm{Cu}$ atoms in austenite were reported to retard the recrystallization of hot-deformed austenite [26]. The $2.0 \mathrm{Cu}$ steel retained non-recrystallized austenite before transformation, which made the AF grains more uniform and fine (Fig. 7c).

$\mathrm{Cu}$, as a solid solution strengthening element, contributes to the strength enhancement to a limited extent in the present study (Table 4). However, high-density fine $\mathrm{Cu}$-rich particles could be obtained without changing the base microstructure (Fig. 7). Accordingly, the strength of the $\mathrm{Cu}$-modified steels after aging was remarkably improved by $\mathrm{Cu}$-rich precipitates (Fig. 5). According to the relationship between microstructure and mechanical properties of the $\mathrm{Cu}$-modified steels, it is noted that the highest strength increase occurs in the $1.5 \mathrm{Cu}$ steel under the condition of aging at $500{ }^{\circ} \mathrm{C}$ for $1 \mathrm{~h}$ (Fig. 5). This can be explained by the synergistic effects of microstructure and $\mathrm{Cu}$-rich precipitates. On the one hand, the more $\mathrm{Cu}$ the steel contains, the higher the strength of the steel was obtained. On the other hand, higher $\mathrm{Cu}$ content in the steel facilitates the coarsening of $\mathrm{Cu}$-rich precipitates, thereby decreasing the hardening effect in the steel. Thus, the optimal $\mathrm{Cu}$ content in the present investigation is $1.5 \%$. It was reported that acicular ferrite played an important role in enhancement of both strength and toughness of pipeline steels [27]. It is believed that a higher strength would be achieved if the $1.5 \mathrm{Cu}$ steel had an acicular ferrite microstructure. In addition, it is interestingly noted that the impact toughness was sharply decreased in the $1.5 \mathrm{Cu}$ steel compared with the $1.0 \mathrm{Cu}$ steel, while a slight decrease in impact toughness occurred in the 2.0 $\mathrm{Cu}$ steel compared with the $1.5 \mathrm{Cu}$ steel at a given aging treatment (Fig. 6). In our previous work, EBSD analysis has been proved that acicular ferrite exhibited more bent crack propagation during the fracture compared with polygonal ferrite [28]. In the present study, the phenomenon could be explained by schematic illustrations of the crack propagation path in $\mathrm{QF}$ $(1.5 \mathrm{Cu})$ and $\mathrm{AF}(2.0 \mathrm{Cu})$ microstructures as shown in Fig. 14 [29]. In the QF structure, the crack propagates straight during fracture, changing its path slightly when meeting with new QF grains (Fig. 14a). However, the AF microstructure, including interwoven non-parallel ferrite laths [9, 17], is complex and the crack frequently bends at boundaries (Fig. 14b). The AF microstructure should have higher impact toughness if two steels had the same $\mathrm{Cu}$ content. Thus, a sudden decrease in impact toughness occurred in the $1.5 \mathrm{Cu}$ steel.

\subsection{Effect of $\mathrm{Cu}$ on Antimicrobial Performance in Cu-modified Pipeline Steel}

$\mathrm{Cu}$ is well known for its inherent antimicrobial effects and is the focus of interest for potential application as an element of antibacterial metal materials [13, 14, 30-34]. Actually, the exact antibacterial mechanisms are still not fully understood [8]. However, it has been known that $\mathrm{Cu}$ ions possess a strong biocidal capability. Antibacterial effect of $\mathrm{Cu}$ is generally contributed to its ability to accept and donate electrons as changing oxidation state between $\mathrm{Cu}^{+}$and $\mathrm{Cu}^{2+}[8]$. This allows $\mathrm{Cu}$ to act as a catalyst for generation of reactive oxygen species that can cause oxidative damage to vital cell constituents such as proteins, nucleic acids or lipids [35]. Nan et al. [30-32] have confirmed that precipitation of $\mathrm{Cu}$-rich phase caused by saturated $\mathrm{Cu}$ in the austenitic stainless steel is a crucial factor to kill the bacteria, and the $\mathrm{Cu}$ ions released from the $\mathrm{Cu}$-rich phase play a dominant role in the antibacterial effect. Wang et al. [33] reported that novel $3 \mathrm{Cr} 13 \mathrm{MoCu}$ martensitic stainless steel subjected to solution treatment following aging showed good antibacterial performance. Xia et al. [14] believed that inhibition of the biofilm was caused by the $\mathrm{Cu}$ ions released from $\mathrm{Cu}$-rich phase in the $2205-\mathrm{Cu}$
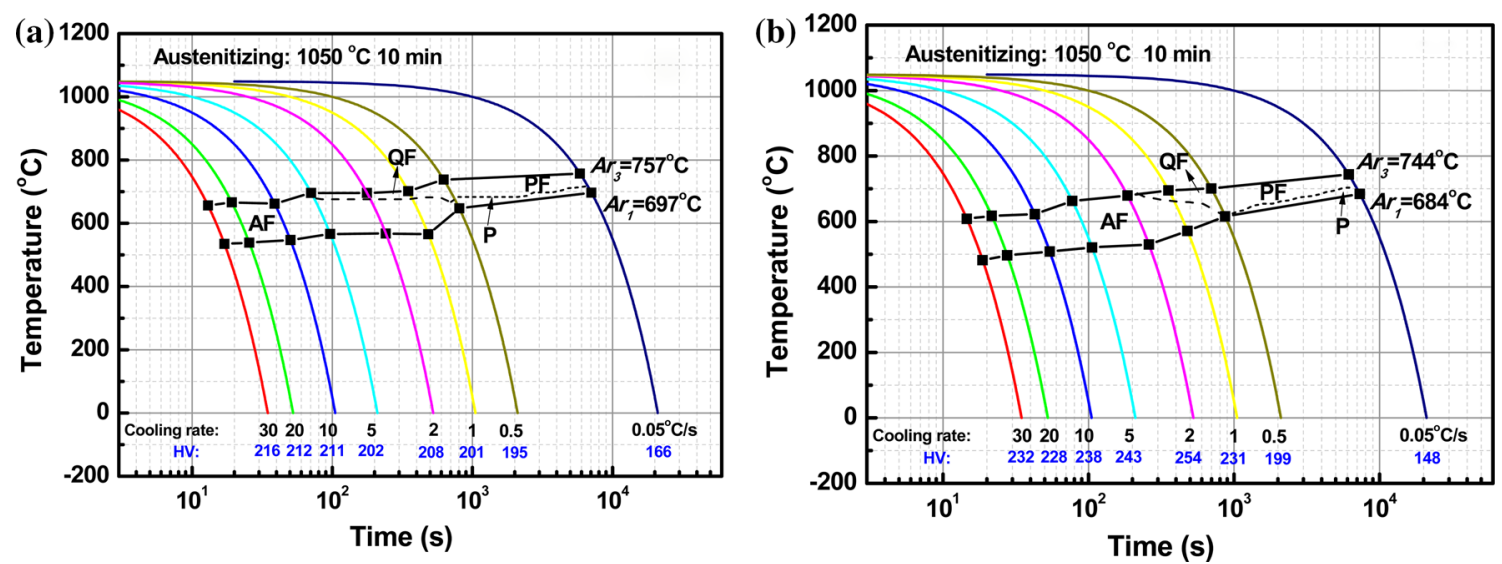

Fig. 13 Continuous cooling transformation diagrams of a $1.5 \mathrm{Cu}$ and $\mathbf{b} 2.0 \mathrm{Cu}$ steels 

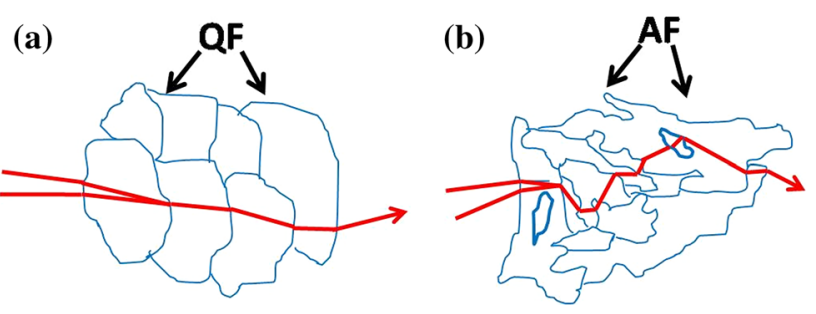

Fig. 14 Schematic illustrations of the crack propagation path in quasi-polygonal ferrite $(\mathrm{QF})$ of the $1.5 \mathrm{Cu}$ steel $\mathbf{a}$ and acicular ferrite (AF) of the $2.0 \mathrm{Cu}$ steel $\mathbf{b}$

duplex stainless steel, leading to its effective mitigation of MIC by Pseudomonas aeruginosa. In the present study, the number of planktonic SRB reached the maximum from day 4 to day 6 . Accordingly, the $R_{\mathrm{LPR}}$ values of two steels declined sharply (Fig. 10). For the Cu-bearing steel, $\mathrm{Cu}$ ions on the surface released from the $\mathrm{Cu}$-rich phase resulted in SRB death, and the $R_{\mathrm{LPR}}$ of $1.0 \mathrm{Cu}$ steel was higher than that of X80 steel. As a result, the pits were significantly inhibited by SRB attack. Therefore, $1.0 \mathrm{Cu}$ steel presented a good antimicrobial effect and distinctly suppresses the occurrence of pitting (Fig. 11). However, there are still some unknown factors of the novel pipeline steel to be understood. For instance, what is the exact antibacterial mechanism for the $\mathrm{Cu}$-bearing steel? Do the steel release $\mathrm{Cu}$ ions like the $\mathrm{Cu}$-bearing stainless steel? Based on the good antimicrobial performance of the $\mathrm{Cu}$ bearing pipeline steel, we will continue to carry out deeper studies to answer the above questions in the near future. In addition, pipeline steels, used for transportation of oil and gas, require high strength and high toughness as well as excellent resistance to HIC [36]. Many issues should be considered, such as possibility to be highly rolled at higher temperature, formability, weldability, etc. Therefore, many studies on development of novel $\mathrm{Cu}$-modified pipeline steels should be pursued in the future. Fortunately, the precipitation of $\mathrm{Cu}$-rich particles in the newly developed $\mathrm{Cu}$-modified pipeline steels is very fast (Fig. 3). Therefore, this new type of pipeline steels may be coiled at temperature range of $500-550{ }^{\circ} \mathrm{C}$ after TMCP (Fig. 12). This processing step can be potentially used as the aging treatment for the hot-rolled plates without requiring any additional processing for $\mathrm{Cu}$ precipitation.

\section{Conclusions}

Novel Cu-modified pipeline steels showed the typical age hardening and over-aging softening behaviors at the aging temperature of $450-600{ }^{\circ} \mathrm{C}$ from $10 \mathrm{~min}$ to $10 \mathrm{~h}$, and the $1.5 \mathrm{Cu}$ steel achieved the highest hardness increase after aging at $500{ }^{\circ} \mathrm{C}$ for $1 \mathrm{~h}$. The aging response was significantly more rapid at a higher aging temperature, and the peak-aging time can be well predicted from the hardness results. There is no significant free energy barrier for the nucleation process of $\mathrm{Cu}$-rich precipitates. These make it possible to coil the hot-rolled $\mathrm{Cu}$-modified steel plates after TMCP without requiring any additional processing step for $\mathrm{Cu}$ precipitation strengthening.

$\mathrm{Cu}$ lowered the austenite-to-ferrite transformation temperature and led to an increase in the driving force for the acicular ferrite transformation. Thus, the microstructures of $\mathrm{Cu}$-modified pipeline steels were transformed from PFdominated microstructure in the $1.0 \mathrm{Cu}$ steel to $\mathrm{QF}-$ dominated microstructure in the $1.5 \mathrm{Cu}$ steel and further to $\mathrm{AF}$ dominated microstructure in the $2.0 \mathrm{Cu}$ steel at a given cooling rate with increase in the $\mathrm{Cu}$ content.

The $\mathrm{Cu}$-modified steels showed good antimicrobial performance with remarkable strength enhancement by nanoscale $\mathrm{Cu}$-rich precipitates and good impact toughness without changing the original microstructures at the optimal aging treatment of $500{ }^{\circ} \mathrm{C} / 1 \mathrm{~h}$.

Acknowledgements The authors would like to acknowledge the financial support by the National Key Technologies R\&D Program of China (No. 2011BAE25B03). Thanks are given to Prof. Wei Sha at the Queen's University for his language polishing on this article.

\section{References}

[1] S.Y. Li, Y.G. Kim, K.S. Jeon, Y.T. Kho, Met. Mater. 6, 281-286 (2000)

[2] B.W.A. Sherar, I.M. Power, P.G. Keech, S. Mitlin, G. Southam, D.W. Shoesmith, Corros. Sci. 53, 955-960 (2011)

[3] D. Xu, Y. Li, F. Song, T. Gu, Corros. Sci. 77, 385-390 (2013)

[4] T. Wu, M. Yan, D. Zeng, J. Xu, C. Yu, C. Sun, W. Ke, Acta. Metall. Sin. (Engl. Lett.) 28, 93-102 (2015)

[5] R. Javaherdashti, Anti-Corros. Methods Mater. 46, 173-180 (1999)

[6] H. Kanematsu, D.M. Barry, Biofilm and Materials Science, Chapter 21 (Springer, Switzerland, 2015), pp. 169-174

[7] L. Ren, Z. Ma, M. Li, Y. Zhang, W. Liu, Z. Liao, K. Yang, J. Mater. Sci. Technol. 30, 699-705 (2014)

[8] J. O'Gorman, H. Humphreys, J. Hosp. Infect. 81, 217-223 (2012)

[9] X. Shi, W. Yan, W. Wang, Y. Shan, K. Yang, Mater. Des. 92 , 300-305 (2016)

[10] L. Ren, L. Nan, K. Yang, Mater. Des. 32, 2374-2379 (2011)

[11] D. Ye, J. Li, W. Jiang, J. Su, K. Zhao, Mater. Des. 41, 16-22 (2012)

[12] T. Xi, C.G. Yang, M.B. Shahzad, K. Yang, Mater. Des. 87, 303-312 (2015)

[13] L. Nan, D.K. Xu, T. Gu, X. Song, K. Yang, Mater. Sci. Eng., C 48, 228-234 (2015)

[14] J. Xia, C.G. Yang, D.K. Xu, D. Sun, L. Nan, Z.Q. Sun, Q. Li, T. Gu, K. Yang, Biofouling 31, 481-492 (2015)

[15] X. Shi, W. Yan, W. Wang, Zhenguo Yang, Y. Shan, K. Yang. ISIJ Int. 56, 2284-2289 (2016)

[16] S.K. Ghosh, A. Haldar, P.P. Chattopadhyay, Mater. Chem. Phys. 119, 436-441 (2010) 
[17] X.B. Shi, W. Yan, W. Wang, L.Y. Zhao, Y.Y. Shan, K. Yang, J. Iron. Steel Res. Int. 22, 937-942 (2015)

[18] M.C. Zhao, K. Yang, Y.Y. Shan, Mater. Lett. 57, 1496-1500 (2003)

[19] H. Mirzadeh, A. Najafizadeh, Mater. Chem. Phys. 116, 119-124 (2009)

[20] A. Seko, S.R. Nishitani, I. Tanaka, H. Adachi, E.F. Fujita, Calphad 28, 173-176 (2004)

[21] U.K. Viswanathan, P.K.K. Nayar, R. Krishnan, Mater. Sci. Technol. 5, 346-349 (1989)

[22] S. Wang, C. Yang, M. Shen, K. Yang, Mater. Technol. 29, 257-261 (2014)

[23] R. Rana, W. Bleck, S.B. Singh, O.N. Mohanty, Mater. Lett. 61, 2919-2922 (2007)

[24] S.S.G. Banadkouki, D. Yu, D.P. Dunne, ISIJ Int. 36, 61-67 (1996)

[25] S.K. Ghosh, N. Bhowmik, A. Haldar, P.P. Chattopadhyay, Mater. Sci. Eng., A 527, 1082-1088 (2010)

[26] A. Takahashi, M. Iino, ISIJ Int. 36, 241-245 (1996)

[27] M.C. Zhao, K. Yang, Y.Y. Shan, Mater. Sci. Eng., A 335, 14-20 (2002)
[28] W. Wang, Y.Y. Shan, K. Yang, Mater. Sci. Eng., A 502, 38-44 (2009)

[29] S.Y. Shin, S.Y. Han, B. Hwang, C.G. Lee, S. Lee, Mater. Sci. Eng., A 517, 212-218 (2009)

[30] L. Nan, W. Yang, Y. Liu, H. Xu, Y. Li, M. Lu, K. Yang, J. Mater. Sci. Technol. 24, 197-201 (2008)

[31] L. Nan, Y. Liu, M. Lu, K. Yang, J. Mater. Sci. Mater. Med. 19, 3057-3062 (2008)

[32] L. Nan, J. Cheng, K. Yang, J. Mater. Sci. Technol. 28, 1067-1070 (2012)

[33] S. Wang, C. Yang, D. Xu, K. Yang, M. Shen, Acta Metall. Sin. 50, 1453-1460 (2014). (in Chinese)

[34] K. Hina, S. Shamaila, Z. Nosheen, S. Rehana, N. Jawad, R. Mohammad, G. Sheeba, S. Hussain, Acta Metall. Sin. (Engl. Lett.) 29, 748-754 (2016)

[35] C.E. Santo, E.W. Lam, C.G. Elowsky, D. Quaranta, D.W. Domaille, C.J. Chang, G. Grass, Appl. Environ. Microbiol. 77, 794-802 (2011)

[36] X.B. Shi, W. Yan, W. Wang, L.Y. Zhao, Y.Y. Shan, K. Yang, Acta Metall. Sin. (Engl. Lett.) 28, 799-808 (2015) 